\title{
Validating Biosecurity Principles for Indigenous Chicken Scale
}

\author{
Fredrick Onyango Aila ${ }^{1, *}$, Dr. Isaac Ochieng ${ }^{2}$, Dr. David Oima ${ }^{1}$ \\ ${ }^{1}$ Maseno University, Kenya \\ ${ }^{2}$ Laikipia University, Kenya \\ *Corresponding Author: fredrick.aila@gmail.com, onyanngo@yahoo.com
}

Copyright $@ 2013$ Horizon Research Publishing All rights reserved.

\begin{abstract}
Indigenous chicken are populous in most developing countries, supporting the livelihoods of many rural folks yet are produced under very low or no biosecurity principles, leading to low productivity. Consumers on the contrary, exhibit high preferences for indigenous chicken. The research question was: what are the consumer attitudes on biosecurity principles for indigenous chicken? The aim of the study was to validate a psychometric scale to measure consumer attitudes on biosecurity principles for indigenous chicken. The sub-aims were to reduce scale so it clearly measures the constructs and to test one hypothesis: H0: There are no significant consumer attitudes on biosecurity principles for indigenous chicken in Kisumu City, Kenya. Starting from a 74-item with $4: 1$ subject to item ratio biosecurity principles for indigenous chicken scale constructed using Fishbein's Multiattribute model, the hypothesis was tested on pilot data gathered from 300 students of a large university in Kisumu County, Kenya using maximum likelihood factor analysis. Reliabilities for each biosecurity principle ranged from $\alpha=.817$ to $\alpha=.817$ respectively. Initial KMO were low ranging between .519 to .595 but improved significantly after refining the scale. Only one factor was extracted from each principle based on theory. Each extracted factor explained variances ranging from $25.099 \%$ to $34.307 \%$ respectively, though $<50$ percent. A total of 37 items loaded on these four factors with respect to the four biosecurity principles. The factor matrices for each extracted factor were significant at $p=.000$ and $p<.05$ respectively. Thus the null hypothesis was rejected. The results can further be confirmed in subsequent studies.
\end{abstract}

Keywords Maximum Likelihood, Exploratory Factor Analysis, Principal Component Analysis, Fishbein Multi-Attribute Model, Biosecurity Principles, Perceived Benefits, Perceived Concerns

\section{Introduction}

Indigenous chicken are populous in most developing countries and supports the livelihoods of many rural folks (Sonaiya and Swan, 2004). They are produced under very low or no biosecurity principles (Nyaga, 2007a) which is a major challenge for the sub-sector (Okeno, Kahi and Peters, 2010). Hence, their productivity is very low (Omiti, 2011). Consumers on the contrary, exhibit high preferences for indigenous chicken. They are willing to pay a premium price for it (Bett et al., 2011). This high preference, given very low levels of indigenous chicken biosecurity, is paradoxical (Aila, 2012). Little research on consumer attitudes on biosecurity principles for indigenous chicken is available. The research question was: what are the consumer attitudes on biosecurity principles for indigenous chicken? The aim of the study was to validate a psychometric scale to measure consumer attitudes on biosecurity principles for indigenous chicken. The sub-aims were to reduce scale so it clearly measures the constructs and to test one hypothesis: H0: There are no significant consumer attitudes on biosecurity principles for indigenous chicken in Kisumu City, Kenya.

Fishbein Multi-Attribute Model (Fishbein and Ajzen, 1975) can aid in constructing consumer attitudes. It is well recognized as an established framework for explaining attitude, intention and choice. It has widespread acceptance for use in consumer research and for its values in explicating attitudes (Agarwal and Malhotra, 2005; Kim, 2009). In measuring attitudes, one should locate the subject on bipolar affective or evaluative dimension on a given object (Fishbein and Ajzen, 1975).

Biosecurity is a relatively new word in common vocabulary and is not found in many dictionaries and thesauri. Its broad meaning is the literal safety of living things, or the freedom from concern of sickness or disease (Amass and Clark, 1999). It is security from transmission of infectious diseases, parasites and pests to a poultry production unit (Permin and Detmer, 2007); and the implementation of policies and procedures that prevent the introduction and spread of disease (Nyanga, 2007a).

Four biosecurity principles: management of the flock; control of incoming animals; control of in- and out- going material; and control of other animals have been proposed (Permin and Detmer, 2007). These four have been adapted to 
indigenous chicken production (Nyaga, 2007b). Consumer attitudes for indigenous chicken have been proposed (Aila et al., 2012) but have not been validated so far.

Exploratory factor analysis can be used to validate new scales (Costello and Osborne, 2005). The most commonly used exploratory factor analysis technique is Principal Component Analysis (PCA) (Chukwuone et al. 2006; Akinnagbe, 2010; Hair et al., 2010). PCA has however been criticized for not being a factor analysis technique at all despite its common usage (Fabrigar et al, 1999). Maximum likelihood, principal factors, and iterative principal factors have been proposed as better alternatives to PCA in factor extraction (Costello and Osborne, 2005). Maximum Likelihood Factor Analysis has particularly been proposed to be a superior exploratory factor analysis technique as it allows for the computation of a wide range of indexes of the goodness of fit of the model (Fabrigar et al., 1999). These fit measures are intended to assess the degree to which a given model provides an approximation of observed correlations and covariances.

\section{Methodology}

Starting from a 74 item biosecurity principles for indigenous chicken scale (Aila et al., 2012) constructed using Fishbein's Multiattribute Model (Fishbein and Ajzen, 1975), a descriptive study to validate the scale was designed. The respondents were asked to express their beliefs and levels of agreement measured on a Likert scale, with scores typically anchored at the extremes 1 and 7 where $1=$ Strong disagree, $2=$ Disagree, $3=$ Somewhat disagree, $4=$ Neither agree or disagree, $5=$ Somewhat agree, $6=$ Agree, and $7=$ Strongly agree (Vagias, 2006; Caracciolo et al., 2011). The reconstructed instrument was administered on 300 students of a large university campus in Kisumu County,
Kenya (Brooker, 1975; Nunnaly, 1978; De Vallis, 1991; Lee et al., 1997; Sow and Grongnet, 2010). Bahia and Nantel (2000) used 300 students to validate their scale. Respondents were selected using systematic sampling technique (Saunders et al., 2003). The data were analyzed using descriptive statistics to exhibit their exploratory capacity. Factors were extracted using maximum likelihood (ML) exploratory factor analysis (Costello and Osborne, 2005). Theoretically, the set of items under each biosecurity principle represented one factor. Thus, the number of factors to be retained was determined a priori. Given the choice of ML, the oblique rotation was performed.

\section{Results and Discussion}

The response was impressive at $100 \%$ with females being $23 \%(n=300)$ of respondents. The ages of the respondents were below 20 years- $22 \%, 21-30$ years $74 \%$ and the rest $4 \%$ $(n=300)$ respectively. The sample size was adequate for using factor analysis (Nunnaly, 1978; DeVallis, 1991; Bahia and Nantel, 2000; Labar, 2008; Kulscasr, 2010). The subject to item ratio was $4: 1$ within the range of acceptability (Castello and Osborne, 2005). Majority of exploratory factor analysis studies in their survey $(62.9 \%, N=303)$ had researchers perform analyses with subject to item ratios of 10:1 or less, which is a prevalent rule of the thumb (Castello and Osborne, 2005).

The questionnaire had a reliability of $\alpha=.914$ for all 114 items. The biosecurity principles for indigenous chicken scale had a reliability of $\alpha=.911$ for its 74 items. Each biosecurity principle had an acceptable reliability (management of the flock, $\alpha=.817$; control of other animals, $\alpha=.635$; control of in-coming and out-going materials, $\alpha=.820$ and control of other animals, $\alpha=.536$ ) respectively as shown in Table 1 below.

Table 1. Reliability Statistics

\begin{tabular}{|c|c|c|c|}
\hline & $\begin{array}{c}\text { Cronbach's } \\
\text { Alpha }\end{array}$ & $\begin{array}{c}\text { Cronbach's Alpha Based } \\
\text { on Standardized Items }\end{array}$ & N of Items \\
\hline Management of the Flock & .817 & .819 & 31 \\
\hline Control of Incoming Animals & .635 & .638 & 9 \\
\hline Control of In-coming and Out-going Materials & .820 & .823 & 29 \\
\hline Control of Other Animals & .536 & .539 & 5 \\
\hline Biosecurity principles for indigenous chicken scale & .911 & .913 & 74 \\
\hline Questionnaire & .914 & & 114 \\
\hline
\end{tabular}

Source: Pilot data, 2012.

The item means was $\mu=4.654(S D=.784)$ signifying somewhat agreement with the items. The scale mean was $\mu=344.36(S D=58.049)$ for the 74 items. Table 2 and 3 below presents these results. 
Table 2. Summary Item Statistics

\begin{tabular}{|c|c|c|c|c|c|c|c|}
\hline & Mean & Minimum & Maximum & Range & $\begin{array}{c}\text { Maximum / } \\
\text { Minimum }\end{array}$ & Variance & N of Items \\
\hline Item Means & 4.654 & 3.772 & 5.479 & 1.707 & 1.452 & .161 & 74 \\
\hline Inter-Item Correlations & .124 & -.422 & .730 & 1.152 & -1.731 & .023 & 74 \\
\hline
\end{tabular}

Source: Pilot data, 2012

Table 3. Scale Statistics

\begin{tabular}{|c|c|c|c|}
\hline Mean & Variance & Std. Deviation & N of Items \\
\hline 344.36 & 3369.650 & 58.049 & 74 \\
\hline
\end{tabular}

Source: Pilot data, 2012.

Kaiser-Meyer-Olkin (KMO) measure of sampling adequacy $K M O=.247$ and Bartlett's test of sphericity $x^{2}=$ $25479.569 \mathrm{df}=2701(\mathrm{p}=.000)$ were performed to test the factorability of the scale. Found that the scale as a whole had low factorability. Thus, we opted to perform similar tests for each biosecurity principle. Each biosecurity principle was found to be factorable as shown in Table 4 below. For each biosecurity principle, KMO was $>.5$ which is interpreted as miserable (George and Mallery, 2009). The Bartlett's test of sphericity for each principle was significant at $\mathrm{p}=.000$ signifying construct validity (Roberts-Lombard, 2013) as shown in Table 4 below.

Table 4. KMO and Bartlett's Test at the Beginning

\begin{tabular}{|c|c|c|c|c|c|c|}
\hline & & Scale & $\begin{array}{l}\text { Management of } \\
\text { the Flock }\end{array}$ & $\begin{array}{l}\text { Control of } \\
\text { Incoming } \\
\text { Animals }\end{array}$ & $\begin{array}{c}\text { Control of } \\
\text { In-coming and } \\
\text { Out-going } \\
\text { Materials } \\
\end{array}$ & $\begin{array}{l}\text { Control of Other } \\
\text { Animals }\end{array}$ \\
\hline \multicolumn{2}{|c|}{$\begin{array}{l}\text { Kaiser-Meyer-Olkin Measure of Sampling } \\
\text { Adequacy. }\end{array}$} & .247 & .595 & .592 & .583 & .519 \\
\hline \multirow{3}{*}{$\begin{array}{l}\text { Bartlett's Test of } \\
\text { Sphericity }\end{array}$} & Approx. Chi-Square & 25479.569 & 4615.901 & 579.568 & 3814.877 & 174.844 \\
\hline & Df & 2701 & 496 & 36 & 406 & 10 \\
\hline & Sig. & .000 & .000 & .000 & .000 & .000 \\
\hline
\end{tabular}

Source: Pilot data, 2012

After several iterations, the following results were produced using ML extraction method and oblique rotation. The 74 item instrument was refined to produce a more parsimonious 37 item scale. Management of the flock extracted one factor represented by 13 items explaining $29.374 \%$ of total variance. Control of incoming animals extracted one factor represented by 6 items explaining $28.458 \%$ of total variance. Control of incoming and outgoing materials extracted one factor represented by 14 items. This explained $25.099 \%$ of total variance. Lastly, control of other animals extracted one factor represented by 4 items explaining $34.307 \%$ of total variance. The KMO of the refined scale for respective biosecurity principles showed marked improvements. Both management of the flock and control of incoming and outgoing materials had KMO improving from $>.5$ to $>.7$ respectively. Control of incoming animals showed KMO improve from $>.5$ to $>.6$ while control of other animals remained at $\mathrm{KMO}>.5$ (see Table 5 below).

Table 5. KMO and Bartlett's Test after Factor Extractions

\begin{tabular}{|c|c|c|c|c|c|}
\hline \multirow{2}{*}{} & $\begin{array}{c}\text { Management of the } \\
\text { Flock }\end{array}$ & $\begin{array}{c}\text { Control of } \\
\text { Incoming Animals }\end{array}$ & $\begin{array}{c}\text { Control of } \\
\text { In-coming and } \\
\text { Out-going } \\
\text { Materials }\end{array}$ & $\begin{array}{c}\text { Control of Other } \\
\text { Animals }\end{array}$ \\
\hline Kaiser-Meyer-Olkin Measure of Sampling Adequacy. & .773 & .641 & .735 & .573 \\
\hline \multirow{2}{*}{$\begin{array}{c}\text { Bartlett's Test of } \\
\text { Sphericity }\end{array}$} & Approx. Chi-Square & 1564.242 & 354.197 & 1312.041 & 135.127 \\
\cline { 2 - 6 } & Df & 91 & 15 & 406 & 6 \\
\cline { 2 - 6 } & Sig. & .000 & .000 & .000 & .000 \\
\hline
\end{tabular}

Source: Pilot data, 2012

We examined the scree plots for each biosecurity principle to ascertain whether the number of factors retained as tandem with theory was replicated by the data. Both Fig. 1 and 3 below show that one factor was rightly extracted, even though the 
variance explained was below 50 percent. Fig. 2 and 4 below show that more than one factor should have been extracted.

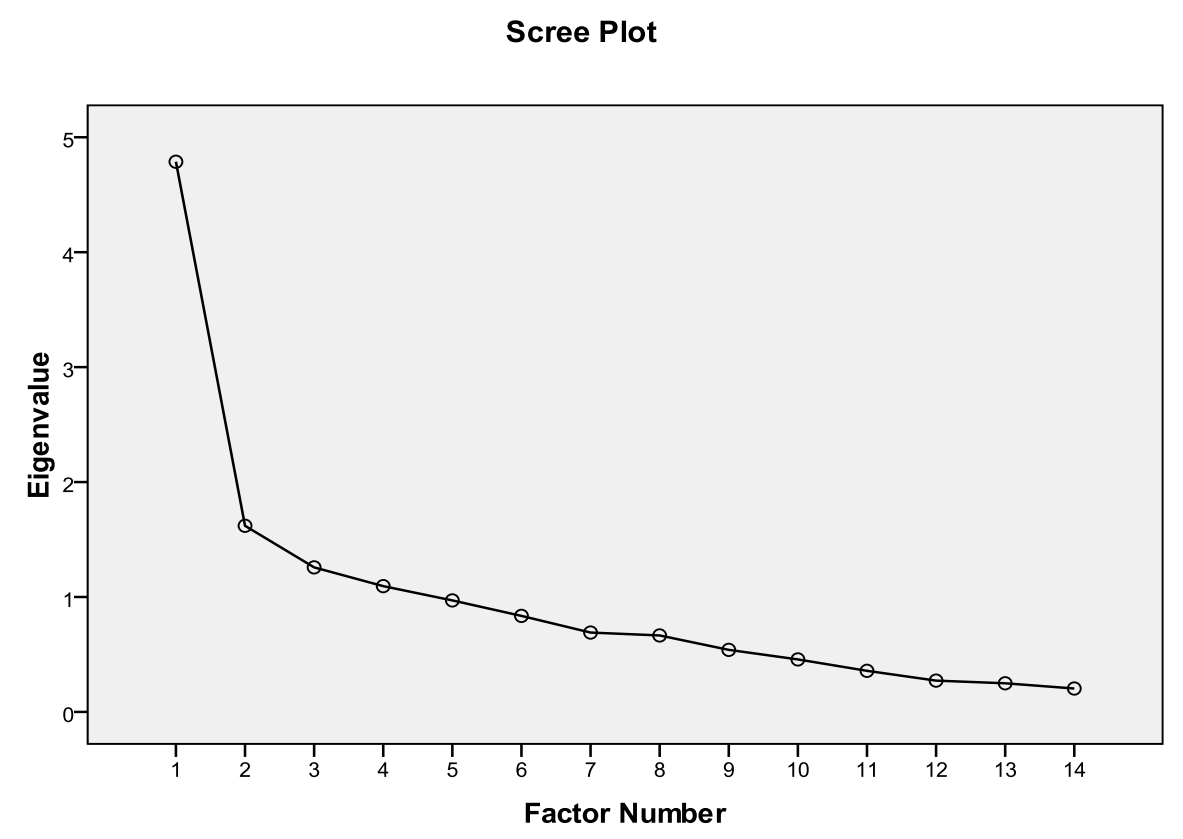

Figure 1. Management of the Flock (Variance explained $=29.374 \%$

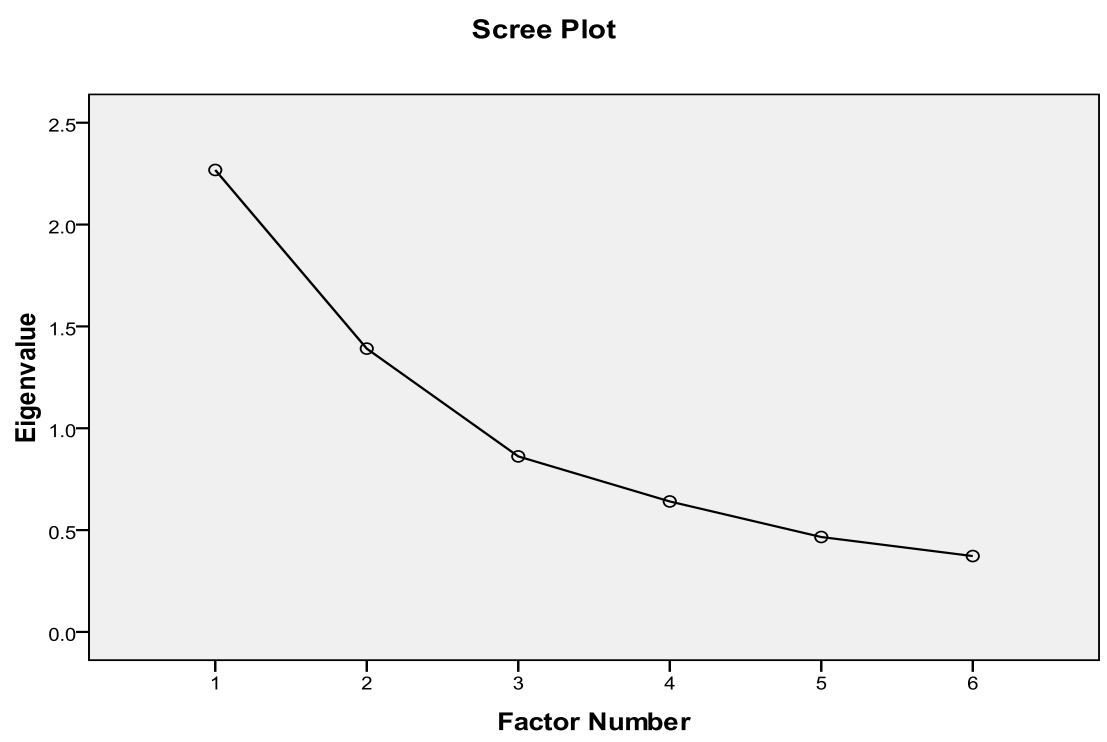

Figure 2. Control of Incoming Animals (Variance explained=28.458\%) 


\section{Scree Plot}

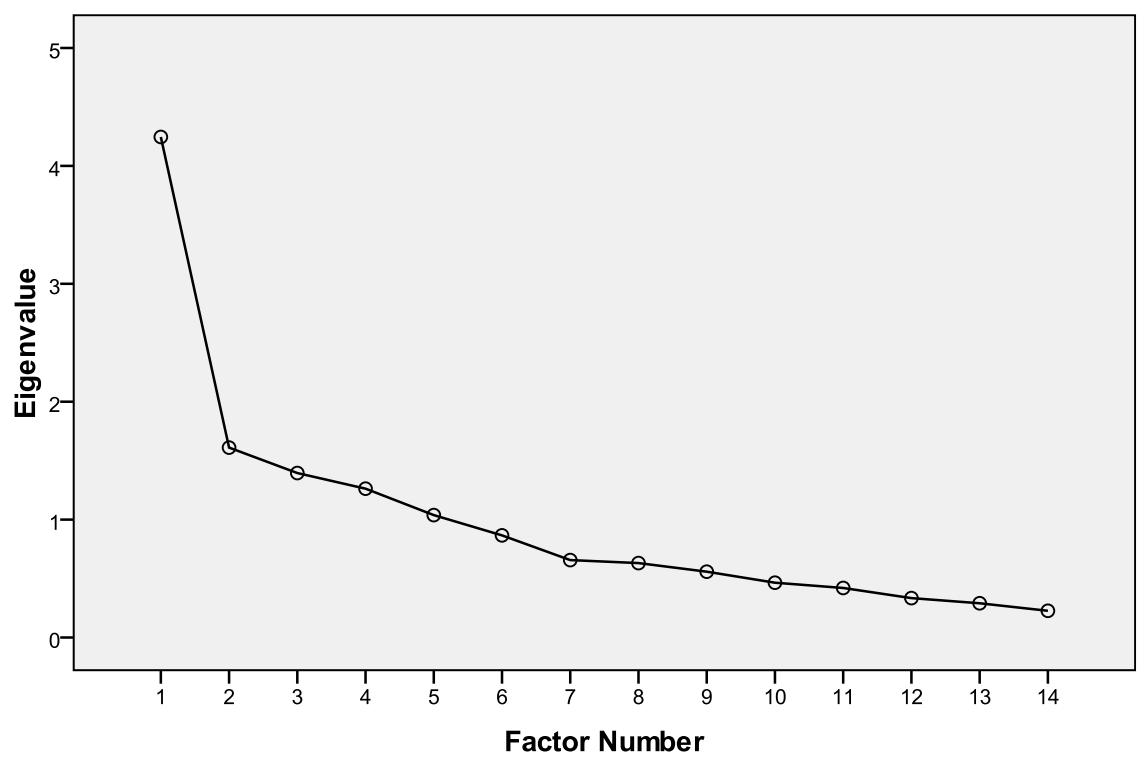

Figure 3. Control of incoming and outgoing materials (Variance explained $=25.099 \%$ )

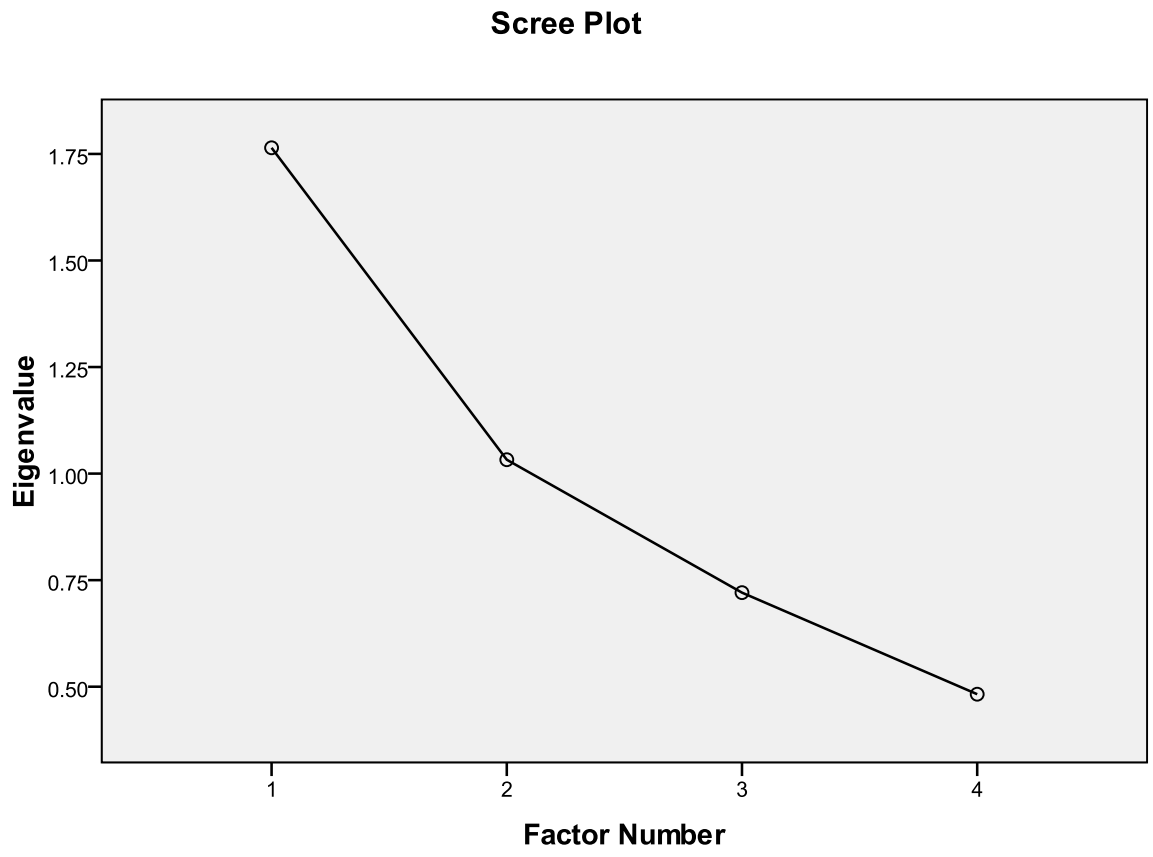

Figure 4. Control of other animals (34.307\%)

Appendix 1-4 below presents the factor matrices for each of the four biosecurity principles. In Appendix 1, the 13 item factor matrix of management of the flock is presented. All items have factor loadings $>.30$ and the scale is significant at $x^{2}=624.868 \mathrm{df}=77(\mathrm{p}=.000)$ (Table 6 below). Factor loadings ranged from .311 to .740 respectively. "Observing regular personal hygiene such as washing of hands, and use of clean or dedicated clothes and shoes is a beneficial practice," (.740) loaded highly on the factor. It was construed as a perceived benefit of this biosecurity principle (Nyaga, 2007b). "Isolating flocks from situations that expose them to diseases is preventive in nature" even though 
a perceived benefit had the lowest factor loading. Both "Most farmers raise flocks using home-grown skills" (.353); "Attendants wear domestic cloths while on duty without protective head gears and footwear" (.366) and "Non-vaccinated flocks tend die of diseases such as Newcastle Disease (NCD)" (.588), the only biosecurity concerns extracted loaded lowly to moderately on the factor.

Appendix 2 presents the factor matrix of six control of incoming animals principle. Four items had factor loadings $>.30$ whiles the remaining two less than it. "Use of appropriate disinfectants in the hatchery and in the brooding house minimizes disease occurrence" (.742) and "Separately brooding indigenous chicks (chicks alone or chicks together with mother hen) for at least three weeks of their life ensures their adaptability to their new environment" (.812) had strong loadings on the factor. These two biosecurity protocols if observed are beneficial as they ensure survivability of new flocks (Okeno, Kahi and Peters, 2010). "Day old chicks are not exposed to dirty environments" (.225) and "Clean beddings are provided for brooding hens" (.226) loaded lowly on this factor. These items were negatively scored. In theory, day old chicks are exposed to dirty environments; moreover, no clean beddings are given to brooding hens among indigenous chickens (Nyaga, 2007b). Inclusion of these two items in the final scale was justified on the basis of the overall fit of the factor model. Deleting either or both of these factors would have yielded an insignificant goodness of fit. With their inclusion, the factor was significant at $x^{2}=96.947 \mathrm{df}=9(\mathrm{p}=$ .000) (Table 6 below).

Appendix 3 presents the factor matrix of 14-item control of incoming and outgoing materials. Only two items loaded highly on the factor. These are "The small proportion that does not get inspected may need to be identified and be brought into the inspection loop" (.631) reflecting a biosecurity concern and "Identifying clean and dirty processes in the farm, sales and slaughtering processes so as to avoid contaminating clean areas is logical" (.610) reflecting a biosecurity benefit. A total of 11 items loaded moderately on the factor: $>.400$ six and $>.5$ five respectively. One item loaded lowly on the factor at $>.3$, that is "The traders themselves act as sources of infectious agents" (.319) which represented a biosecurity concern. All these 14 items were significant at $x^{2}=630.834 \mathrm{df}=77(\mathrm{p}=.000)$ (Table 6 below).

Appendix 4 presents the 4-item factor matrix for control of other animals principle. One item "As birds scavenge they interact with several disease carrying agents" (.983) loaded so highly on the factor as it was a major biosecurity concern (Nyaga, 2007b; Onim, 2002; Kagira and Kayari, 2010; Bird Life International, 2013). The rest loaded very lowly to moderate. In fact, one item, "While on transit, the birds are either exposed to the atmosphere or are in contact with humans" (.281) had a loading <.300 and should have been deleted. Deleting this item would have improved the factor loadings (see Fig. 4 above) but rendered the factor insignificant. Retaining it yielded a significant goodness of fit $x^{2}=9.842 \mathrm{df}=2(\mathrm{p}=.007) \quad($ See Table 6 below). The $x^{2}$ was significant at $\mathrm{p}<.05$ confirming that all four items significantly tapped on the factor.

Table 6. Goodness-of-fit tests

\begin{tabular}{|c|c|c|c|}
\hline & \multicolumn{3}{|c|}{ Goodness-of-fit Test } \\
\hline Biosecurity principle & $\begin{array}{c}\text { Chi-Squar } \\
\mathrm{e}\end{array}$ & Df & Sig. \\
\hline Management of the flock & 624.868 & 77 & .000 \\
\hline $\begin{array}{c}\text { Control of incoming animals } \\
\text { Control of incoming and outgoing } \\
\text { materials }\end{array}$ & 96.947 & 9 & .000 \\
\hline \begin{tabular}{c} 
Control of other animals \\
\hline
\end{tabular} & 9.842 & 2 & .007 \\
\hline
\end{tabular}

Source: Pilot data, 2012

From the analysis presented above, the goodness-of-fit test (see Table 6 above) was used to test the hypothesis:

$H_{0}$ : There are no significant consumer attitudes on biosecurity principles for indigenous chicken in Kisumu City, Kenya.

Each of the biosecurity principles had significant factor matrices for each factor representing a biosecurity principle. Thus the null hypothesis was rejected and the alternate accepted.

\section{Conclusion}

The study set to validate a psychometric scale to measure consumer attitudes on biosecurity principles for indigenous chicken. There were twin sub-aims: to reduce scale so it clearly measures the constructs and to test one hypothesis. Using pilot data, with 4:1 subject to item ratios, the 74-item scale was reduced to a more parsimonious 37 -item scale using maximum likelihood exploratory factor analysis. The variance explained by each single factor representing respective biosecurity principle was rather low $<50$ percent. Observing the scree plots, biosecurity principles that had large number of items $>20$, extracted a single factor that explained the largest variance. The principles with $<10$ items did not significantly extract a single factor. Further deletions could have produced stronger single factors. The null hypothesis, $H_{0}$ : There are no significant consumer attitudes on biosecurity principles for indigenous chicken in Kisumu City, Kenya was rejected as the goodness-of-fit tests revealed that respective factor matrices for biosecurity principles was significant at $\mathrm{p}=.000$ and $\mathrm{p}<.05$ respectively. Thus, the alternative hypothesis $H_{1}$ : There are significant consumer attitudes on biosecurity principles for indigenous chicken in Kisumu City, Kenya was accepted. Further study may be needed to refine this scale and to confirm its applicability to the context at hand. 


\section{APPENDIX 1: Management of the Flock Factor Matrix ${ }^{a}$}

\begin{tabular}{|c|c|}
\hline Management of the Flock & $\begin{array}{c}\text { Factor } \\
1\end{array}$ \\
\hline Farmers grouped in farmer associations tend to vaccinate their flocks routinely. & .581 \\
\hline Non-vaccinated flocks tend die of diseases such as Newcastle Disease (NCD). & .588 \\
\hline A disinfectant dip placed at the door of each house can prevent entry of diseases agents into the flock house. & .568 \\
\hline $\begin{array}{l}\text { Poultry houses facilitate parasite and disease control. They promote faster growth and protect the chicken from predatory birds and animals } \\
\text { and adverse weather conditions and theft during the night as well as during the day time. }\end{array}$ & .483 \\
\hline Clothes dedicated for handling chicken worn in the poultry house would reduce chances of entry disease into the flock houses. & .460 \\
\hline Training in good husbandry practices for all poultry farmers can improve biosecurity measures markedly. & .556 \\
\hline A program of educating farmers on the role and usefulness of isolation and other biosecurity measures can be developed and implemented & .565 \\
\hline Observing regular personal hygiene such as washing of hands, and use of clean or dedicated clothes and shoes is a beneficial practice. & .740 \\
\hline Clothes dedicated for handling chicken, which may not necessarily be new, should be provided for use exclusively in the flock houses. & .589 \\
\hline There are adequate feeding troughs and watering equipment for all birds in the poultry house. & .332 \\
\hline Attendants wear domestic cloths while on duty without protective head gears and footwear. & .366 \\
\hline Most farmers raise flocks using home-grown skills. & .353 \\
\hline Isolating flocks from situations that expose them to diseases is preventive in nature. & .311 \\
\hline
\end{tabular}

Extraction Method: Maximum Likelihood.

a. 1 factors extracted. 5 iterations required.

Source: Pilot data, 2012

\section{APPENDIX 2: Control of Incoming Animals Factor Matrix ${ }^{\mathrm{a}}$}

Control of incoming animals

Factor

1

Day old chicks are not exposed to dirty environments $\quad .225$

$\begin{array}{ll}\text { Clean beddings are provided for brooding hens. } & .226\end{array}$

Laying nests are provided for layer birds. $\quad .329$

Protocols and procedures in the hatcheries if monitored regularly can assure they supply clean day old chicks free from bacterial and viral agents that may emanate from hatcheries.

Use of appropriate disinfectants in the hatchery and in the brooding house minimizes disease occurrence.

Separately brooding indigenous chicks (chicks alone or chicks together with mother hen) for at least three weeks of their life ensures their adaptability to their new environment.

Extraction Method: Maximum Likelihood.

a. 1 factors extracted. 5 iterations required.

Source: Pilot data, 2012 


\section{APPENDIX 3: Control of In- and Out-going Materials Factor Matrix ${ }^{a}$}

\begin{tabular}{|c|c|}
\hline Control of In- and Out-going Materials & $\begin{array}{c}\text { Factor } \\
1\end{array}$ \\
\hline Feeds often get contaminated at its administration by fecal matter/chicken droppings containing disease agents. & .452 \\
\hline Manure and slaughter wastes are disposed on the farm. These are accessible to both domestic and wild animals. & .524 \\
\hline Risks of disease causing agents are inherent within the trade cycle. & .482 \\
\hline $\begin{array}{l}\text { For farm-, market- or restaurant-slaughtered birds, the concern is on where and how the waste water, feathers and offals, which may lead } \\
\text { to spreading of disease, are disposed. }\end{array}$ & .423 \\
\hline The traders themselves act as sources of infectious agents. & .319 \\
\hline The risks at the slaughtering process are many e.g. dry defeathering scatters feathers all over the sales areas at the local markets. & .481 \\
\hline $\begin{array}{l}\text { For wet defeathering, the disposal of waste water, the offals, the feathers and the presence of worn out cement floors, the presence of bird } \\
\text { cages and storage of personal effects in the cages that also held chickens poses a big risk. }\end{array}$ & .523 \\
\hline Indigenous chicken sold in live markets, slaughtered at market-, restaurant-, home-backyard are seldom inspected. & .517 \\
\hline There is no formal inspection carried out for eggs except grading. & .517 \\
\hline Poultry feed that is free from disease agents should be kept in a clean, dry store free from rodents and insect pests. & .580 \\
\hline A disinfectant dip at the entrance to the flock houses keeps at bay pathogens and prevents from escaping into or out of the poultry house. & .405 \\
\hline Use of disinfectants to decontaminate materials and equipment that has gone to the market before it is re used at the farm is prudent. & .461 \\
\hline Identifying clean and dirty processes in the farm, sales and slaughtering processes so as to avoid contaminating clean areas is logical. & .610 \\
\hline The small proportion that does not get inspected may need to be identified and be brought into the inspection loop. & .631 \\
\hline
\end{tabular}

Extraction Method: Maximum Likelihood.

a. 1 factors extracted. 4 iterations required.

Source: Pilot data, 2012

\section{APPENDIX 4: Control of Other Animals Factor Matrix ${ }^{a}$}

\begin{tabular}{l} 
CONTROL OF OTHER ANIMALS \\
\hline As birds scavenge they interact with several disease carrying agents. \\
Wild birds' attractants (spilled feeds, open water spots, dead carcasses) are seldom removed from the poultry compound. \\
While on transit, the birds are either exposed to the atmosphere or are in contact with humans. \\
There is evidence of domestic birds mixing with wild birds. \\
Extraction Method: Maximum Likelihood.
\end{tabular}

a. 1 factors extracted. 22 iterations required.

Source: Pilot data, 2012

\section{REFERENCES}

[1] Agarwal, J., \& NK. Malhotra (2005). An integrated model of attitude and affect: Theoretical foundation and an empirical investigation. Journal of Business Research,58 (4): 483-493.

[2] Aila, FO., D. Oima, Ochieng', I., Ojera, PB. and Odhiambo 
Odera (2012). Construction and validation of consumer attitudes on biosecurity principles: A methodological perspective. Research on Humanities and Social Sciences, Vol.2, No.6, 2012 ISSN 2224-5766(Paper) ISSN 2225-0484(Online) pp240-250.

[3] Akinnagbe, OM. (2010). Constraints and strategies towards improving cassava production and processing in Enugu North Agricultural Zone of Enugu State, Nigeria. Bangladesh J. Agril. Res. 35(3) pp387-394.

[4] Amass, SF., \& KL. Clark (1999). Biosecurity considerations for pork production units. Swine Health Prod. 7(5) pp.217-228.

[5] Bahia, K. \& J. Nantel (2000). A reliable and valid measurement scale for the perceived service quality of banks, International Journal of Bank Marketing, vol 18 no. 2 pp84-91.

[6] Bett, H., Peters, K., Nwankwo, U., \& W. Bokelmann (2011). Estimating consumer preferences and willingness to pay for the underutilised indigenous chicken products. Tropentag, October 5-7, 2011, Bonn accessed from http://www.tropentag.de on 2/6/12.

[7] Bird Life International (2013). East Asia/East Africa Flyway. Retrieved on 22 February 2013 from http://www.birdlife.org/datazone/userfiles/file/sowb/flyways 16_East_Asia_East_Africa_Factsheet.pdf.

[8] Brooker, B. (1975). An Instrument to Measure Consumer Self-Actualization. in Schlinger, MJ., A. Abor, eds. Advances in Consumer Research Volume 02, Association for Consumer Research, Pages: 563-576.

[9] Caracciolo, F., Coppola, A. \& F. Verneau (2011). Validation of a psychometric scale to measure consumers' fears of modern food technologies. International European Forum on System Dynamics and Innovation in Food Networks, International European Forum, February 14-18, 2011, Innsbruck-Igls, Austria. [Accessed on 1 April 2012] http://purl. umn.edu/122005. pp160-174.

[10] Chukwuone, NA., Agwu, AF., \& N. Ozor (2006). Constraints and strategies towards effective cost-sharing of agricultural technology delivery in Nigeria: Perceptions of farmers and agricultural extension personnel. Journal of International Agricultural and Extension Education, Vol. 13(1) pp29-41.

[11] Costello AB. And JW. Osborne (2005).Best practices in exploratory factor analysis: Four recommendations for getting the most from your analysis. Practical Assessment Research \& Evaluation, Vol. 10, No. 7. pp1-8

[12] DeVellis, RF. (1991). Scale development: Theory and applications. Newbury Park, CA: Sage, p. 85.

[13] Fabrigar, LR., DT. Wegener, RC. MacCallum, and EJ. Strahan (1999). Evaluating the use of exploratory factor analysis in psychological research. Psychological Methods, Vol. 4. No. 3 pp 272-299.

[14] Fishbein M. \& I. Ajzen (1975). Belief, attitude, inten $\neg$ tion and behavior: An introduction to theory and research. Addison-Wesley Publishing, Reading (MA).

[15] George, D. \& P. Mallery (2009). SPSS for Windows step by step: A simple guide and reference 16.0 update, 9th ed. Boston: Pearson.
[16] Hair, JF. Jr., Black, WC., Babin, BJ., \& RE. Anderson (2010). Multivariate data analysis: A global perspective, 7th Edn, , Upper Saddle River, New Jersey: Pearson.

[17] Kagira, JM. and Kanyari, PWN. (2010). Questionnaire survey on urban and peri-urban livestock farming practices in Kisumu municipality, Kenya. Journal of the South African Veterinary Association, 81(2): 82-86 (En.). Trypanosomiasis Research Centre, Kenya Agricultural Research Institute, PO Box 362, Kikuyu, Kenya.

[18] Kim, RB. (2009). Factors influencing Chinese consumer behavior when buying innovative food products. Agric. Econ. - Czech, 55, 2009 (9): 436-445.

[19] Kulcasr, E. (2010). Principal component analysis in tourism marketing. Management and Marketing, Vol. 5 (2). Pp151-158.

[20] Labar, AV. (2008) SPSS for education, Polirom: Iasi.

[21] Lee, MS., Sandler, DM. \& D. Shani (1997). Attitudinal constructs towards sponsorship: Scale development using three global sporting events. International Marketing Review, Vol. 14 no.3 pp. 159 - 169.

[22] Meat Control Act (2012). Meat Control (Poultry Meat Inspection) Regulations, 1975, in Meat Control Act, Cap 356, Laws of Kenya, Kenya Law Reports. Retrieved on 5/6/2013 from www.kenyalaw.org

[23] Nunnally, JC. (1978). Psychometric theory. New York: McGraw-Hill Book Company.

[24] Nyaga, P. (2007a). The structure, marketing and importance of the commercial and village poultry industry: An analysis of the poultry sector in Kenya. Rome, Food and Agriculture Organization (FAO) of the United Nations.

[25] Nyaga, P. (2007b). Good biosecurity practices in small scale commercial and scavenging production systems in Kenya. Rome, Food and Agriculture Organization (FAO) of the United Nations.

[26] Okeno, T.O., Kahi, A.K. \& J.K. Peters (2010). Characterization of indigenous chicken production systems in Kenya: Household flock structure, dynamics and breeding practices. Proceedings of the 12th KARI Biennial Scientific Conference, Kenya Agricultural Research Institute.

[27] Omiti, J. (2011). Poultry farming hits a wall in Kenya. Retrieved from www.poultrypro. com/africa/poultry on March 30, 2011.

[28] Onim, M. (2002). Final report of scoping study for urban and peri-urban livestock keepers in Kisumu City, Kenya. Lowland Agricultural and Technical Services Limited (Lagrotech), Kisumu, Kenya.

[29] Permin, A. \& A. Detmer (2007). Improvement of management and biosecurity practices in smallholder producers. Rome: Food and Agricultural Organization of the United Nations.

[30] Roberts-Lombard Mornay, Lauren Strachan and Leon du Plessis (2013). The influence of trust, commitment and conflict-handling on customer loyalty: a parallel investigation. Journal of Economic and Financial Sciences | JEF | 6(1), pp. 195-216.

[31] Saunders, M., Lewis, P. \& A. Thornhill (2003). Research 
methods for business students, 3rd ed. London: Prentice Hall-Financial Times.

[32] Sonaiya, EB. \& SEJ. Swan (2004). Small-scale poultry production: Technical guide. FAO Animal Production and Health. Rome: Food and Agriculture Organization of the United Nations.
[33] Sow, TMA. \& JF. Grongnet (2010). Sensory characteristics and consumer preference for chicken meat in Guinea, Poultry Science, 89:2281-2292.

[34] Vagias, WM. (2006). Likert-type scale response anchors. Clemson International Institute for Tourism \& Research Development, Department of Parks, Recreation and Tourism Management. Clemson University. 